\title{
Richard Flanagan's The Narrow Road to the Deep North and Matsuo Basho's Oku no Hosomichi
}

\author{
Yasue Arimitsu \\ Doshisha University \\ yasuearimitsu@gmail.com
}

\begin{abstract}
Copyright $(2017$ Yasue Arimitsu. This text may be archived and redistributed both in electronic form and in hard copy, provided that the author and journal are properly cited and no fee is charged, in accordance with our Creative Common Licence.
\end{abstract}

\begin{abstract}
This paper investigates Australian author Richard Flanagan's novel, The Narrow Road to the Deep North, and attempts to clarify the reason why Flanagan chose this title, which is linked to the travel writings of the Japanese author Matsuo Basho, for his novel. The novel focuses on the central character's prisoner of war experience on the Thai-Burma Death Railway during World War II, and depicts the POW camp as well as cruel Japanese behaviour and atrocities in a realistic way. The work seems to provide a postcolonial framework in the sense that there is a colonial and postcolonial relationship between the colonizer, and the colonized. However, in this novel, the colonizer is Eastern, and the colonized is Western, and this fact reverses postcolonial theory which postulates a structure in which the colonizer is usually considered as Western and the colonized, Eastern. Postcolonial theory, thus, cannot be applied in this novel, which attempts to fuse the two opposites, the Western view and the Eastern view, through the work of the Japanese poet. As a result, Flanagan, in writing The Narrow Road to the Deep North, goes beyond being a postcolonial writer to become a writer in a globalizing age.
\end{abstract}

Keywords: POW camp; The Burma-Thailand railway; Matsuo Basho's haiku poems 


\section{Introduction}

Richard Flanagan is a contemporary Australian writer from Tasmania. He was born in Longford, Tasmania, in 1961 and brought up in a remote mining town on Tasmania's western coast. Flanagan left school at the age of 16 but returned to study at the University of Tasmania, where he was president of the Tasmania University Union in 1983. He graduated with a Bachelor of Arts with First-Class Honours. The following year, he was awarded a Rhodes Scholarship at Worcester College, Oxford, where he was admitted to the degree of Master of Letters in History. Before he started to write fiction, he wrote four non-fiction works, which he has called "his apprenticeship." His books have been awarded a number of prizes, such as the Commonwealth Writers' Prize, the New Yorker Book of the Year, the Observer Book of the Year, the Queensland Premier's Prize, the Western Australian Premier's Prize and the Tasmania Book Prize.

He is considered by many to be the finest Australian novelist of his generation. ${ }^{2} \mathrm{He}$ has written 6 novels so far and two of them have been translated into Japanese: Gould's Book of Fish: A Novel in Twelve Fish (2001) ${ }^{3}$ and The Unknown Terrorist (2006). ${ }^{4} \mathrm{He}$ was awarded the 2014 Man Booker Prize for fiction for his sixth novel The Narrow Road to the Deep North (2013), which is the object of this study. The Man Booker Prize is one of the most prestigious prizes for fiction and until 2013 it had been awarded for novels written in English and only authors in the Commonwealth, including the UK, the Republic of Ireland and Zimbabwe were eligible for consideration. From 2014, however, the rules were changed to extend eligibility to any novel written in English. Therefore, the case of Flanagan is the first time in the award's history that authors from the United States of America have been included. Two Australian authors before Flanagan won this prize: Thomas Keneally and Peter Carey.

In this paper, I intend to investigate Australian author Richard Flanagan's novel, The Narrow Road to the Deep North, whose title is an English version of Oku no Hosomichi, a haibun travel collection of haiku poems and prose written by the Japanese poet, Matsuo Basho. The story of this novel is about the central character's experience as a prisoner of war of the Japanese on the Thai-Burma Death Railway, and his illicit love affair with his uncle's wife. I am very much interested in why Flanagan chose this title for the novel, and in how well Flanagan is versed in the knowledge of Japanese haiku poems. In the novel, Flanagan also quite often mentions Tennyson's poem, "Ulysses," main character Dorrigo. In this paper, I would like to examine the link between Basho's work and Tennyson's "Ulysses" to ascertain whether there is any relationship between 
them. I also intend to verify whether this novel can be analyzed using a postcolonial framework; the colonizers and the colonized, and the Western perspective and the Eastern perspective, as the novel highlights two opposite Australian and Japanese views of the experiences of World War II, and at the same time, attempts to reconcile the viewpoints of two hostile countries in World War II, and eventually, fuse the views of the East and the West.

\section{The POW Camp and the Burma-Thailand Railway}

Richard Flanagan wrote The Narrow Road to the Deep North, in a sense, as homage to his father, who worked on the railway as a prisoner of war and survived but saw a great number of friends and compatriots die in horrific conditions. Flanagan spent 12 years writing this novel based on his father's stories, and he says that his father died aged 98 on the day the book was finished. The novel revolves around the life of the physician, Dorrigo Evans, a flawed war hero and survivor of the Burma Railway, also known as the Death Railway, where more than 12,000 Allied prisoners and 90,000 Asian labourers lost their lives. Dorrigo is a character modeled after war hero Edward "Weary" Dunlop, ${ }^{5}$ who looked after his men as they struggled under the most heinous conditions to clear jungle, break rocks and lay rails from Ban Pong, Thailand, and Thanbyuzayat, Burma, ${ }^{6}$ Dunlop looked after his comrades, "living skeletons," who were dying of malaria, beri-beri and cholera and tried to protect them from their Japanese captors, some of whom were sadists who took the greatest pleasure in tormenting, torturing and beheading prisoners. According to Roger Pulvers, an Australian playwright who is very familiar with Japanese literature, after the war, Dunlop returned to an illustrious career in Australia, and he openly "forgave the cold-blooded and tyrannical Japanese who tortured and murdered the men on the Burma-Thailand railway" (Pulvers).

This novel, however, bears little resemblance to the one the French writer, Pierre Boulle, offered in the early 1950s in The Bridge Over the River Kwai, ${ }^{7}$ as Michael Gorra remarks. Flanagan uses the word "Kwai" exactly twice, and Gorra assumes that Flanagan "has something much deeper than revisionism on his mind, though, something even deeper than his pungent account of the prisoners' life on the Line" (Gorra). Flanagan, in fact, remarks about the novel in an interview with Lorien Kite:

I think that more than his [Flanagan's father's] stories, which were comic but imbued with a certain compassion and pity, what I absorbed from him and what 
it took me so long to understand was an idea of life very different from most people's," Flanagan says. "It was an idea about love - an idea of always meeting other human beings as equal and never as less than you. (Kite)

Flanagan said that he had two purposes in writing this novel: the first was that his father was growing old and frail, and he felt that if he couldn't finish this book while he was alive, he wouldn't be able to go on writing. The other was the realization that it had to be a love story. He says:

I think if people are presented with a picture of only darkness they revolt against it because they know, fundamentally, that it's untrue to their experience of life, which is to hope," he says. "If war illuminates love, love offers the possibility of allowing some light to be brought back out of the shadows. It's almost as if they buttress and make possible an understanding of each other. (Kite)

Cruel Japanese behavior and atrocities during World War II are quite well known and Flanagan's realistic depictions of those scenes provide readers (including Japanese readers) with information about what happened at the POW camp. Particularly, through the Japanese officers Major Nakamura and Colonel Kota, Flanagan shows us the savage and violent treatment of the Australian prisoners; the unbearably prolonged beating to death of Darky Gardiner was emphasized, "as if man existed only to transmit violence to ensure its domain is eternal" (Flanagan 294-295 ${ }^{1}$ ).

However, Flanagan's way of depicting these cruel Japanese deeds or atrocities was rather objective - neutral as he explained in one of his interviews. Flanagan says, in writing this novel, he was not going to express his feelings of accusation, judgment or hatred towards Japanese officers, but was rather very careful not to make the readers feel that way (Koval). The depiction of cruel scenes could be observed from double viewpoints; one Australian and the other, Japanese. Flanagan considers Japanese officers as human beings and their cruel deeds and atrocities as human behavior in war, and places them in a historical context:

For the world did not change, this violence had always existed and would never be eradicated, men would die under the boot and fists and horror of other men until the end of time, and all human history was a history of violence. (295)

\footnotetext{
${ }^{1}$ All references to Flanagan's novel by page numbers only henceforwarth.
} 
It is quite obvious that Flanagan is trying to understand why all those Japanese officers could be so cruel to the Australian prisoners, treating them as victims of the war just like the Australian prisoners. Those who were trapped in the suffering and hardships of this scene were not only the Australian prisoners, but also the Japanese officers:

And Nakamura could see that, in this sacrifice too, there was no other way for the Emperor's wishes to be realized. What was a prisoner of war anyway? Less than a man, just material to be used to make the railway, like the teak sleepers and steel rails and dog spikes. If he, a Japanese officer, allowed himself to be captured, he would be executed on his ultimate return to home islands anyway.

Whatever the circumstances Nakamura might have to put up with, such as lack of tools and manpower, he would endure and the railway would be built, the war would be won, and all this would be because of the Japanese spirit. The Japanese spirit has a special meaning for Nakamura, which has something to do with "the ancient wisdom of Japan, of all that Nakamura found good and best in his country, in his own life" (115).

It was good and it was pure, and it was for him a more real force than the thorny bamboo and teak, the rain and mud and rocks and sleepers and steel rails they worked with each day. It had somehow become the essence of him, and yet it was a thing beyond words. (115)

Nakamura, however, would not have known what the Japanese spirit precisely meant, and he could not even explain it in words. He was, in fact, himself confused about what he believed in, but he could not find any other way to survive except to become violent toward the prisoners as he thought to himself: "It wasn't in his nature to be so harsh. But in the face of the Australians' intransigence, he had to be. If they had spirit, Nakamura said, they would have chosen death rather than the shame of being a prisoner" (117). He justifies himself in his own way: "There was no choice in any of this: one existed for the Emperor and for the railway - which was, after all, the embodiment of the Emperor's will — or one had no reason to live or even die" (288). This scene seems to be the interpretation of Flanagan's Japanese spirit at this stage in his depiction of the character of Major Nakamura, but here Flanagan was not really able to grasp the meaning of the Japanese spirit.

In order to solve this absurdity or irrationality, Nakamura had had to devote himself to his 
duty in the service of the Japanese spirit, which is equivalent to the Emperor. This is what non-Japanese people, including Dorrigo Evans, could not understand; the logic of the Japanese spirit and the Japanese Emperor. Even Major Nakamura could not come to terms with this logic, and takes pills of Philopon or shabu in order to accomplish his duties: "Now the shabu was more necessary to him than food" (94). To build such a railway - with no machinery and through a wilderness - was a superhuman task. Fired by shabu, he was able to return to it day after debilitating day with redoubled fervour.

It was not just the railway, as Colonel Kota says, although the railway must be built and the war must be won. Major Nakamura said that the Japanese attempted to show that "it's about the Europeans learning that they are not the superior race," and "us learning that we are," and Colonel Kota recited Basho's haiku poem:

Even in Kyoto

when I hear the cuckoo

I long for Kyoto. (125)

Both Major Nakamura and Colonel Kota here shared a passion for traditional Japanese literature, especially Basho's haiku. Nakamura thought:

In this way, ... the Japanese spirit is now itself the railway, and the railway the Japanese spirit, our narrow road to the deep north, helping to take the beauty and wisdom of Basho to the larger world. (126)

The Japanese spirit was thus embodied by the haiku form of Japanese poetry, and haiku poems helped them feel better "about their own privations and the bitter struggle that was their work" (127). Nakamura murmured a haiku poem of Basho when the guards were kicking a sick prisoner, Darky Gardiner, and asked Japanese officer, Fukuhara, to recite the poem in English translation for Dorrigo Evans:

\footnotetext{
A world of pain-

if the cherry blossoms,

it blossoms. (292)
}

Hearing this poem, Dorrigo Evans understood that the railway had to be built, that the railway was the only reason for the immense suffering of hundreds of thousands of human beings at that very moment. He even thought that Darky Gardiner must be punished (292). Dorrigo Evans started to consider Major Nakamura not as the strange but a human officer 
just like him, not a harsh but a pragmatic commander (293). Dorrigo Evans now understood that, in the situation of war, everyone had a role to play and had to put it into practice. He could accept this as he was a part of it (294). This is the point that made Dorrigo Evans understand the behavior of Major Nakamura and other cruel Japanese officers, and here Flanagan used Basho's haiku poems which seem to symbolize some kind of solace beyond words, logic, or rationality in the inhuman situation of the war.

It is very significant to note that Flanagan mentions, along with Basho's haiku, the Japanese short story, 'Rashomon,' in the novel. 'Rashomon' was written by the very famous Japanese author Akutagawa Ryunosuke (1897-1927), and was a great influence on modern Japanese writers. 'Rashomon' is a story about the human will to survive and is associated with the situation of the Japanese officer, Major Nakamura, after the war.

'Rashomon' is set in the Heian Period $\left(8^{\text {th }}-11^{\text {th }}\right.$ centuries $)$ when Japanese society was very unstable and a lot of crimes occurred. There was a big gate called Rashomon in Kyoto (it was actually a building similar to a temple), but it had been dilapidated for a long time because of the social disorder caused by the difficulty of obtaining food and prevalence of diseases. One samurai who was in a desperate situation having lost his job, strolled about in the rain and came to the Rashomon gate, which was then used for storing dead bodies in the attic. In the attic, the samurai found an old woman, who was stealing hair from a dead woman in order to sell it. The samurai accused her of being a thief, but the woman justified herself by saying that the dead old woman was a fraud when she was alive. Having heard this story, the samurai decided to live as a thief to survive, and robbed the old woman of her clothes.

The story seems to tell that in order to survive, you are allowed to sacrifice others. This is reminiscent of the logic of Major Nakamura, as Flanagan writes at the beginning of the novel: "War, though, is its own logic" (23). The Japanese Empire has the belief that it will win - the indomitable Japanese spirit, "that spirit that the West does not have, that spirit it calls and understands the Emperor's will; it is this spirit that it believes will prevail until its final victory" (23-24). The Japanese officers had to play their roles to construct the Line, otherwise they would die. This is the reason why they could be violent to the prisoners; they were violent in order to fulfill their duties in the name of the Japanese Empire. The prisoners and their captors were thus all caught up in the same trap of war; they were all victims of the war. Thus, Flanagan shows that wars bring about nothing but the will to survive.

After the war and the Line and the dream of a global Japanese empire were shattered after 
the atomic bombs were dropped on Hiroshima and Nagasaki, Major Nakamura was strolling amidst the ruins of Shinjuku, and picked up a newspaper that lay trampled on the ground. He read it carefully, and found that it was about warrants being issued by the Americans for the arrest of more ex-POW camp staff in relation to possible war crimes, and the article ended with a list of the wanted suspects' names. Halfway down the list, he found his name mentioned as a possible Class B war criminal (309). Then he attempted to survive, to avoid capture and execution, because his honour demanded it (310). In the Rashomon-like ruins of Shinjuku, he saw an American soldier and a Japanese boy who were both dead, and an immoral woman who was selling herself to the "American devils" (314). Nakamura was disgusted by this woman and decided to rob her. He scrambled down the Shinjuku Rashomon leaving the woman behind and headed into the city. Nakamura survived by sacrificing a woman just as the samurai in Akutagawa's 'Rashomon' had justified his sacrifice of the old female thief by his own need to survive.

Flanagan said in an interview that "we are all human beings and that evil acts are not theirs but ours" (Kite). This is the reason why Dorrigo Evans understood the Japanese officers as mentioned above. Dorrigo Evans says at the beginning of the novel when referring to his family: "Their principal achievement was survival. It would take him a lifetime to appreciate what an achievement that was" (12). Dorrigo Evans now understood the meaning of his family's survival as immigrants to Australia. It seems as if Flanagan intended to make Dorrigo Evans understand how Australian prisoners survived just as Japanese officers survived the war.

After the war ended, Major Nakamura, returning home to Japan, told himself: ... through his service of this cosmic goodness, he had discovered he was not one man but many, that he could do the most terrible things he might otherwise have thought were evil if he had not known that they were in the service of the ultimate goodness. For he loved poetry above all, and the Emperor was a poem of one word - perhaps, he thought, the greatest poem - a poem that encompassed the universe and transcended all morality and all suffering. And like all great art, it was beyond good and evil. (392)

Major Nakamura knows that he did the most terrible things at the war camp but he justifies himself by believing that he did the right thing in the service of ultimate goodness; constructing the Line for the greatest poem, that is the Emperor. This is how Flanagan portrayed Major Nakamura in the novel. For Flanagan, Nakamura was a survivor but, at the same time, a victim of the war just as the Australian soldiers. Flanagan said in a conversation with Ramona Koval: 
He [Flanagan's father] said that he was very lucky, that they were the best thing that ever happened to him, to be in these camps, because they only had to suffer. He felt that to go to war as a soldier means for most people that you have to inflict suffering, and then, if you survive it, you have to live with the fact that you acted as an agent of evil. He felt they were in a situation where they would discover, not the worst of themselves, but the best. (Koval)

Flanagan thus attempted to describe human beings from multiple viewpoints and treated the characters who inflicted suffering and those upon whom suffering was inflicted at the same level. Just as Flanagan's father said he was lucky because he did not have to inflict punishment or pain on other people, the Australian prisoners and Japanese officers are not portrayed as enemies: the colonized and the colonizers - they were victims in the same war. Flanagan observed both sides equally without any inclination to either of them.

\section{Dorrigo Evan's Love Story}

Flanagan says that the novel is not about the war, about the Japanese POW camp, or about the cruel experiences of Australian soldiers, but a love story, "all about the beauty of human beings in the most extraordinary circumstances" (Kite). The work is, in fact, a saga, a historical novel about Dorrigo Evans, which starts from his childhood and depicts how he was brought up in Tasmania, a reflection of the author's background, and then how he became a doctor, married Ella, a woman from a good family, with the hope of leading a happy married life. However, when he was engaged to Ella, he accidentally fell in love with Amy, who was his uncle's wife. Flanagan connects Dorrigo's love story with his experience of the POW camp.

At the beginning of the novel, Dorrigo Evans, memorized poems by Tennyson, which were no longer very popular (18). When he read Tennyson's 'Ulysses,' he was only a young man and did not know who and what he was in the deepest recesses of his being. While he was a successful physician, he was a relentless womanizer and deceived his wife by having adulterous relationships with a number of women and continued to lie, manipulate and deceive. Therefore, his estimation of himself was realistically "low" (17). He felt rather negative in trying to find solid meaning in his life: 
Dorrigo Evans understood that all his life had been journeying to this point when he had for a moment flown into the sun and would now be journeying away far from it forever after. Nothing would ever be as real to him. Life never had such meaning again. $(9-10)$

For Dorrigo, Tennyson's 'Ulysses' and Amy, his lover, were the "first beautiful thing[s]" (13) he ever knew. She was very special although he met her outside of his marriage, and he read and reread 'Ulysses' when he was lying in bed in a hotel with Amy, watching the moon rise over the valley of her belly:

The long day wanes: the slow moon climbs: the deep

Moans round with many voices. Come, my friends,

'Tis not too late to seek a newer world. (13)

As a young man, Dorrigo was a searcher for the meaning of life, but at the same time he was a successful physician in real life, and tried to find a harmony between being a searcher and a physician, although they did not necessarily go well together. Dorrigo was trying to solve these contradictions of two opposites, but then he went to war, was caught by the Japanese military, and went through the hardships of war.

When he was in the POW camp where he experienced those extreme atrocities, he remembered only his illicit relationship with Amy. In such a situation, human beings need something which makes their lives meaningful. For Dorrigo, Amy was an agent of something that might be called love, but it was difficult for him to explain or grasp what it was. Flanagan attempts to show the meaning of life, or the meaning of beauty for Dorrigo through Amy, an agent of Dorrigo's love. Amy was also a searcher for the meaning of life, while hiding her inner life, her true self, a turmoil, that took her elsewhere:

She would know that that love is not goodness, and nor is it happiness. She wasn't necessarily or always unhappy with Keith [her husband], nor were her feelings about Dorrigo always or exactly those of happiness. For Amy, love was the universe touching, exploding within one human being, and that person exploding into the universe. It was annihilation, the destroyer of worlds. (158)

Dorrigo's and Amy's illicit love affair is thus connected to something beyond good or evil just as represented in Tennyson's poem 'Ulysses.' Dorrigo considers Amy perfect: “He watched those perfect spheres of blood, three camellias of desire, continue swelling. Her 
body was a poem beyond memorizing" (132).

Dorrigo's love affair was represented as a poem just as for Nakamura the Japanese spirit was represented as a poem: "the Japanese spirit is now itself the railway, and the railway the Japanese spirit, our narrow road to the deep north, helping to take the beauty and wisdom of Basho to the larger world" (126). Returning to Australia after the war, Dorrigo was not able to fulfill his love with Amy because of an irony of fate. When he learned that Amy was dead, he felt "how empty is the world when you lose the one you love" (413). He, however, finally understood: "it was she who had lived and he who had died, although she had thought him dead for many years" (414).

Dorrigo's love story and his experience of the POW camp are both necessary for Flanagan's purpose in this novel. In this sense, Jennifer Scott is right in saying that "without the love story, the novel would be just another fictionalized account of wartime cruelty and survival, and there have been any number of those" (Scott), while Michiko Kakutani's comment in her New York Times article that "the novel would have been far more powerful and coherent if Amy were excised from the story" (Kakutani) is not relevant to the purpose of Flanagan's novel.

As the guards took turns kicking Gardiner, Nakamura murmured a haiku of Basho. Fukuhara looked at him queryingly:

Yes, Nakamura said. Tell him.

Fukuhara continued staring.

He likes poetry, Nakamura said.

It is very beautiful in Japanese, Fukuhara replied.

Tell him.

In English I think not.

Tell him.

Smoothing the side of his pants with his hands, Fukuhara turned to the Australian. He drew himself up straight, so that his neck seemed even longer, and recited his own translation:

$$
\begin{aligned}
& \text { A world of pain- } \\
& \text { if the cherry blossoms, } \\
& \text { it blossoms. (291-292) }
\end{aligned}
$$

This is the scene when Major Nakamura and Dorrigo Evans, a captor and a prisoner, were linked by Basho's poem, which encompasses the universe and transcends all morality and all suffering, and like all great art, is beyond good and evil (Kite). They share something 
about life which could only be represented by poems.

Dorrigo Evans, at first, was unable to understand the Japanese officers' behavior, and considered them as ridiculous, cruel, or inhuman, but when Dorrigo listens to Nakamura reciting a poem, he began to understand him as a human being just like himself, as already mentioned before. Now, when Nakamura ordered Fukuhara to translate Basho's poem into English for Dorrigo, Dorrigo was able to share the feelings of the poem with Nakamura, something beautiful beyond good and evil. For Dorrigo, it was possible to link Tennyson's 'Ulysses' with Basho's The Narrow Road to the Deep North, both of which are about the journey of life passing through happiness and harshness, good and bad, and at the end of the journey, he came to accept everything he has had in his life as fate and reconciled himself with his life.

In the end all that was left was the heat and the clouds of rain, and insects and birds and animals and vegetation that neither knew nor cared. Humans are only one of many things, and all these things long to live, and the highest form of living is freedom: a man to be a man, a cloud to be a cloud, bamboo to be bamboo. (302-303)

\section{The Narrow Road to the Deep North and Oku no Hosomichi}

Why then did Flanagan choose the English version of Oku no Hosomichi as the title for the novel The Narrow Road to the Deep North? Oku no Hosomichi is the title of a collection of haiku poems written by Basho, one of the most famous Japanese poets of the Edo period. Haiku is widely known as the simplest form of poetry, and Basho wrote Oku no Hosomichi after his journey to the Tohoku district. When he wrote this collection, it is said that Basho had reached the final stage of his life, the stage of "magokoro" (sincerity/true-heartedness in English) which is equivalent to the state of selfless spirit, ${ }^{8}$ and had come to terms with the idea of "fueki ryuko," 9 which means "changeless" and "change," a combination of two opposites. They look different on the surface, but they are the same when simply looked at from different angles. The poems in Oku no Hosomichi are thus Basho's representation of his philosophy of life, "a harmony of two opposites."

Towards the end of Flanagan's novel, Jimmy Bigelow's mind slowly distilled his memory of the POW camps into something beautiful. It was as if he were squeezing out the 
humiliation of being a slave, drop by drop. First he forgot the horror of it all, later the violence done to them by the Japanese. He felt all those things he otherwise didn't feel; he understood all those things he otherwise didn't understand. For him, his words and memories became nothing, as "everything was in him" (432).

And finally one afternoon he realized he could remember none of his time as a POW at all. His mind was still good; he knew he had once been a POW as he knew he had once been a foetus. But of that experience nothing remained. What did was an irrevocable idea of human goodness, as undeniable as it was beautiful. As the age of ninety-four he was finally a free man. (433)

Flanagan visited Japan when he was writing this novel, and unexpectedly met some of the guards from the POW camp. Flanagan felt they had all carried regret and shame. He felt something genuine in their words and that there was regret in them. Returning home to Australia, he told all this to his father, and later that day, his father suddenly lost all memory of the prisoner of war camps, although his mind remained very sharp and alert in every other way. Just like Bigelow in the novel, Flanagan's father knew that he had had this experience-like being in the womb - but he could recall no detail of it. It seemed as if he was finally free of it. Roger Pulvers again says:

Western writers have, for well over a century now, been puzzled by what looks like an inscrutable dichotomy in the Japanese mentality encompassing an excessively cruel streak and one that is utterly gentle, lyrical and compassionate. But this can also be said of all other nationalities; such traits are common, in the $20^{\text {th }}$ century, in the actions and expressions of, for instance, Germans, Russians, Chinese and Americans at war. (Pulvers)

Pulvers might be right in the sense that war can drive people who are usually very gentle to become very cruel and violent. However, it should be noted that Flanagan's The Narrow Road to the Deep North might be one of the most unusual novels in its attempt, through the figures of the Japanese, to understand why human beings could behave like that in war, and its depiction not only of cruelty and absurdity, but also forgiveness and harmony after undergoing violence, suffering and hardship.

In this novel, Flanagan is not simply trying to understand the Japanese mind as a stranger from the Western viewpoint, but is attempting to become at one with the mind represented by Basho's haiku, which Flanagan believes to represent a universal human truth. Flanagan has said on various occasions that he loves Japanese literature, and believes that 
"Basho's writing, like so much of high Japanese culture, is exquisite and beautiful, and rightly regarded as a high point in the history of world literature" (Flanagan, "Freeing my father"). Flanagan even initially attempted to write the story in the form of 'haibun.' 'Haibun' is poetic prose, one of the traditional Japanese literary forms which was particularly employed by Basho and other haiku poets, and Flanagan, by using this form, tried to form a stark contrast between Basho's literary world and his father's experience, as shown in his remark, "If Basho's Narrow Road to the Deep North is one of the high points of Japanese culture, the experience of my father and his mates is one of its low points" (Flanagan, "Freeing my father"). This seems to be the reason why Flanagan used the title of Basho's book, Oku no Hosomichi.

\section{Conclusion}

In this novel, Flanagan wrote about the life of an Australian physician, Dorrigo Evans, a survivor of the Burma Railway, known as the Death Railway, where a great number of Allied prisoners and Asian labourers died. Flanagan used a huge number of pages to depict the POW camp as well as cruel Japanese behavior and atrocities during World War II in a realistic way. However, Flanagan's purpose in writing this novel was not to write about the cruel Japanese deeds or to express his feelings of accusation, judgement or hatred towards Japanese officers, but to consider Japanese officers as human beings and their cruel acts as human behavior in war, and place them in a historical context. Flanagan even made Dorrigo understand why Japanese officers could be so cruel in their treatment of prisoners in war. For Dorrigo, Japanese officers became human beings just like himself and were no longer strangers, and he came to the conclusion that Major Nakamura, a Japanese officer, was as much a victim of the war as the Australian soldiers. In order to survive, Major Nakamura had to inflict punishment or pain on other people, the Australian prisoners. The Australian prisoners and Japanese officers, the colonized and the colonizers, were not portrayed as enemies but as victims of the same war. Flanagan's standpoint in depicting Japanese officers and Australian prisoners was neutral with no inclination towards either of them.

In order to make Dorrigo understand the Japanese officers' cruel behavior towards Australian prisoners, Flanagan used a love story as well as poems. Dorrigo was a successful physician and led a happy married life, but he was not fulfilled by this life, and had a number of love affairs. Dorrigo's illicit love affair with Amy, in particular, was represented by Tennyson's poem 'Ulysses' just as the Japanese spirit for Major Nakamura 
was represented by Basho's haiku poems. Tennyson's 'Ulysses' and Basho's haiku poems were both about the journey of life passing through happiness and harshness, and good and bad. Listening to Basho's poem read in English translation, Dorrigo accepted everything he had experienced in his life as fate and reconciled himself to his life. Tennyson's poem and Basho's haiku poems are thus related to something which encompasses the universe and transcends all morality, as does all great art. It was by Basho's haiku poems in Oku no Hosomichi that Dorrigo Evans and Major Nakamura were linked, and they are Basho's representation of his philosophy of life, "a harmony of two opposites."

This work seems to have a postcolonial framework in the sense that there is a colonial and postcolonial relationship between the colonizer and the colonized. However, the work has a rather complicated structure in terms of the postcolonial theory. In Edward Said's Orientalism, postcolonial theory postulates a structure in which the colonizer is usually considered as Western and the colonized Eastern. But the structure of this work is reversed: the colonizer is Eastern and the colonized Western, if Australians are to be considered Western, and as a result, the theory of postcolonialism in this work cannot directly be applied to the relationship between Australia and Japan.

Instead of advocating or correcting political exploitation or imbalance between Australia and Japan, The Narrow Road to the Deep North has shown a fusion of two oppositesthe Western view and the Eastern view, and brought a harmony to them. This work, therefore, certainly proves that Flanagan has gone beyond being a postcolonial writer to become a writer in a globalizing age, although the issue of language still remains unsolved. We are not really sure whether or not Flanagan had access to Oku no Hosomichi in Japanese, because Basho's poetry expresses not only life, and the beauty of nature and human beings, but most importantly, it shows the beauty of the Japanese language. To genuinely understand his literature, it would be best to read it in Japanese; particularly haiku, the simplest form of poetry in the world, should be read in Japanese. It is quite difficult for us to believe that Flanagan read Basho's haiku poems in Japanese. ${ }^{10}$ However, I should say that, even through translation, Flanagan reaches the beauty of Basho's poetry, shares the reality of human beings, and goes beyond the boundaries of the two opposite worlds, the West and the East, and beyond the postcolonial framework to provide a new view of a globalizing age. 


\section{Works Cited}

Akutagawa, Ryunosuke. "Rashomon.” Akutagawa Ryunosuke Zenshu, Dai 1 Kan. Tokyo: Iwanami Shoten, 1977. 127-136. Print.

Flanagan, Richard. "Freeing my father.” Sydney Morning Herald. 21 September (2013): 24-25. Print.

Flanagan, Richard. The Narrow Road to the Deep North. London: Chatto \& Windus, 2013. Print.

Gorra, Michael. “Bridge to Nowhere, Richard Flanagan's Narrow Road to the Deep North." New York Times Book Review. Sunday, 31August (2014): 12. Print.

Kakutani, Michiko. “A Railroad Built Out of Prisoners' Pain and Sweat." The New York Times. 17 August (2014). Web.

$<$ http://www.nytimes.com/2014/08/18/books/the-narrow-road-to-the-deep-northby-richard-flanagan.html>

Kite, Lorien. "Interview: Richard Flanagan, Man Booker 2014 winter," Financial Times, 17 October (2014). Web. $<$ http://www.ft.com/cms/s/0/cc745fbe-5547-11e4-b750-00144feab7de.html>

Koval, Ramona. "Transcript: Richard Flanagan in Conversation with Ramona Koval." The Monthly. 24 July (2014). Web.

$<$ https://www.themonthly.com.au/transcript-richard-flanagan-conversation-ramonakoval>

Matsuo, Basho. Oku no Hosomichi: New Edition. Trans. into Modern Japanese. Taizo Ebara and Tsutomu Ogata. Tokyo: Kadokawa Bunko, 2014. Print.

Pulvers, Roger. "The Narrow Road to the Deep North.” Japan Times. 9 November (2013). Web. <http://www.japantimes.co.jp/culture/2013/11/09/books/bookreviews/the-narrow-road-to-the-deep-north/ >

Scott, Jennifer. “The 2014 Man Booker Prize Winner: Richard Flanagan's The Narrow Road to the Deep North." Shujitsu English Studies. 31 (2014): 123-129. Print.

\section{Notes:}

1 "Ulysses" is a poem in blank verse by the Victorian poet Alfred, Lord Tennyson (1808-1892), written in 1833 and published in 1842. It is about the mythical hero Ulysses, who, facing old age, describes his discontent and restlessness upon returning to his kingdom, Ithaca, after his far ranging travels. Despite his reunion with his wife Penelope and son Telemachus, Ulysses yearns to explore again. Web. 
$<$ https://en.wikipedia.org/wiki/Ulysses_(poem) >

2 "Love and War, None of it Fair," The Economist, 5 July (2014). Web. $<$ http://www.economist.com/news/books-and-arts/21606246-love-and-war-none-it-fairremembrance>

3 Richard Flanagan, Guurudo Gyorui Gacho: Juuni no Sakana wo Meguru Shosetsu, Tokyo: Hakusui-Sha, 2005.

4 Richard Flanagan, Sugata Naki Terorisuto, Tokyo: Hakusui-sha, 2009.

5 Sir Edward Ernest 'Weary' Dunlop (1907-1993), the army surgeon Colonel, was an extraordinary Australian whose actions embody the compassionate face of war. $\mathrm{He}$ became well known for his medical work and leadership during the Second World War with prisoners of the Japanese on the Thai-Burma Railway, 1943-45. Weary'Dunlop and the Burma Railway -Australian Government. Web.

$<\mathrm{http}$ //www.australia.gov.au/about-australia/australian-story/weary-dunlop>

6 The Burma-Thailand railway was a 415-kilometre (258 mi) railway built by the Empire of Japan in 1943 to support its forces in the Burma campaign of World War II. This railway completed the railroad link between Bangkok, Thailand and Rangoon, Burma (now Yangon). The line was closed in 1947, but the section between Nong PlaDuk and Nam Tok was reopened ten years later in 1957. Burma Railway-Wikipedia. Web. July 17, 2016. <https://en.wikipedia.org/wiki/Burma_Railway>

7 The Bridge Over the River Kwai is a novel by the French novelist Pierre Boulle, published in French in 1952 and in English translation by Xan Fielding in 1954. The story is fictional but uses the construction of the Burma Railway, in 1942-43, as its historical setting and is partly based on Pierre Boulle's own life experience working in Malaysia rubber plantations and later working for allied forces in Singapore and Indochina during World War II. The novel deals with the plight of World War II British prisoners of war forced by the Imperial Japanese Army to build a bridge for the "Death Railway." The Bridge Over the River Kwai-Wikipedia. Web. July 17, 2016.

$<$ https://en.wikipedia.org/wiki/The_Bridge_over_the_River_Kwai>

8 Basho's spiritual attitude was also represented as "karumi," which was obtained through sufferings and hardships, and was equivalent to fundamental and eternal truth of this world that was beyond individual human being. Tsutomu Ogata, "Kaisetsu" for $O k u$ no Hosomichi: New edition. Tokyo: Kadokawa Bunko, 2014, 310.

9 "Fueki ryuko" represents Basho's philosophy of art, that was also the essence of haiku poetry. "Fueki" signifies the unchangeable, and "ryukou" the changeable. Thus the idea of "fueki ryuko" refers to the two opposites: things in this world all change, although this fact never changes. Ogata, "Kaisetsu" for Oku no Hosomichi 307.

10 He probably read Basho's haiku poems in English translation, as there is an excellent translator, Donald Keene, who has translated a number of Japanese literary works, 
including Narrow Road to the Deep North. Keene loves Japan as well as its literature, and was eventually naturalized as a Japanese citizen and now he lives in Japan.

Yasue ARIMITSU is Professor Emeritus of English and Australian Studies, Doshisha University, Japan. She is the author of Finding a Place: Landscape and the Search for Identity in the Early Novels of Patrick White (1986) and Australian Identity: Struggle and Transformation in Australian Literature (2003). She co-authored An Introduction to Australian Studies (2007). She has also edited and contributed to translating Diamond Dog: An Anthology of Contemporary Australian Short Stories-Reflections on Multicultural Society (2008). Her article "Nation and Literature: Literary Possibilities in a Multicultural Society" was published in Wolfgang Zach/Ulrich Pallua (eds.) Racism, Slavery, and Literature (2010). "Nam Le's The Boat: A Reflection of Multiple Selves," appeared in Michael Kenneally, Rhona Kenneally, and Wolfgang Zach (eds), Literatures in English: New Ethical, Cultural, and Transnational Perspectives (2013). She was the president of the Australian Studies Association of Japan (2010-2013), and currently the president of the Australia New Zealand Literary Society of Japan (2014- ).

Acknowledgements: This paper is based on my research supported by the Grants-in-aid for Scientific Research of the Japanese Government. I would like to express my sincere appreciation to all those concerned. 